\title{
A STUDY OF POPULATION DENSITY IN DEVELOPING COUNTRIES
}

\author{
Ida Bagus Ilham MALIK ${ }^{1}$, Wayan SUPARTA ${ }^{2}$, Bart J DEWANCKER
}

DOI: 10.21163/GT_2019.141.34

\begin{abstract}
:
The density of the urban population spreads by land function and geographical condition of the urban land. An understanding of the population density and pattern of distribution will help planners understand the pattern of urban development and urban dwelling trends. Population density and its distribution can be seen through the trend of population density based on the distance of the sub-district center to the city center. Usually, the population density will be high in the city center and will decrease to the suburbs. The research was conducted in 15 cities across Indonesia spread across several main islands of Indonesia and with a diverse population such as geographical area and geographical conditions. Results show that the densest population will be in the center of the city as an economic area, and its density decreases as it progresses further from downtown. This indicates that the population density will rise if it is close to the location of economic activity i.e. downtown, and will decrease when away from the city center.
\end{abstract}

Key-words: Urban Population, Density, Distance, City Center.

\section{INTRODUCTION}

Research conducted by Su et al. (2016) shows a graph of U-shaped population density in cities in China. This study was conducted by combining the population with the users of public transport and land use. Meanwhile, the results of research Oueslati et al. (2015) in European cities indicates that population density and urban sprawl have a correlation when viewed from economic and geographic variables. Research in two different regions and different situations provides an understanding of the population density challenge in both regions. This will help us to understand the demographic and economic policies in each region.

A very interesting study of population density is done by Moos (2015). This study was conducted by looking at the effect of population age on city density and distribution of population density. The results of this study indicate the pattern of population distribution that tends to the economic and market areas. This can affect the population's tendency to use the car as a mobility tool. Because young age gives influence to the desire to own a car. And this will also have an effect on the environment. As the study by Creutzig et al. (2015) resulting in an understanding of the effect of population density on urban energy use and urban air pollution. The study also provides an understanding of urbanization that has an effect on climate change due to urban activity.

\footnotetext{
1 The University of Kitakyushu, Graduate school of Environmental Engineering, Japan, malik80212@gmail.com;

2 Pembangunan Jaya University,Department of Informatics, wayan.suparta@upj.ac.id
} 
City density will also affect the needs of residential buildings. Research conducted by Guneralp et al. (2017) indicates that an increase in home demand has an effect on energy consumption. Meanwhile, the increase in the number of housing caused by the increase of population and the distribution of urban population density. Therefore, control of population density is considered important in order to suppress global warming. Population density presented in spatial format has also been done by Jones et al. (2016). They conducted research on population density on a continental, national, and sub-national scale that had differences in grid cells. The presentation of spatial population density helps us to better understand the pattern of population density.

This study is a preliminary study on the density of the population of several cities in Indonesia, and this study is a very important study to provide an understanding of urban density chart patterns. This chart pattern will help planners and governments to create population policies that are appropriate to the distribution and population density conditions. As a study conducted by Yin et al. (2010) showing the effect of population density on the amount of car ownership and fuel consumption. By knowing this condition, the government will be able to make policy to prevent negative impact. The location of settlements located in the city center will also affect the mobility of the population. This may affect urban policy. Research conducted by Papageorgiou (2014) shows the condition of the urban community's tendency to live in areas close to the city's economic centers or markets.

Our research aims to understand the graph pattern of population density in Indonesia. This understanding will affect the population policy and the determination of the function of urban space in the future. Indonesia has 98 cities with the composition of the number of cities and the proportion of the population as shown in Fig. 1. We selected cities with populations of between 500,000 and $1,500,000$ people, comprising $18.37 \%$ of the total cities in Indonesia. We have hypothesized that cities with populations between 500,000 $1,500,000$, have an ideal population proportion for the size of cities in Indonesia. Therefore, we decided to conduct a study of the city. In this study, we will see the density of all the cities that became the object of study. Color degradation on the city map will show density flow patterns and population density distribution. We will be able to know the tendency of densely populated areas of the city compared to other regions. In this study, population density and distribution of population density are seen from the perspective of district administration.

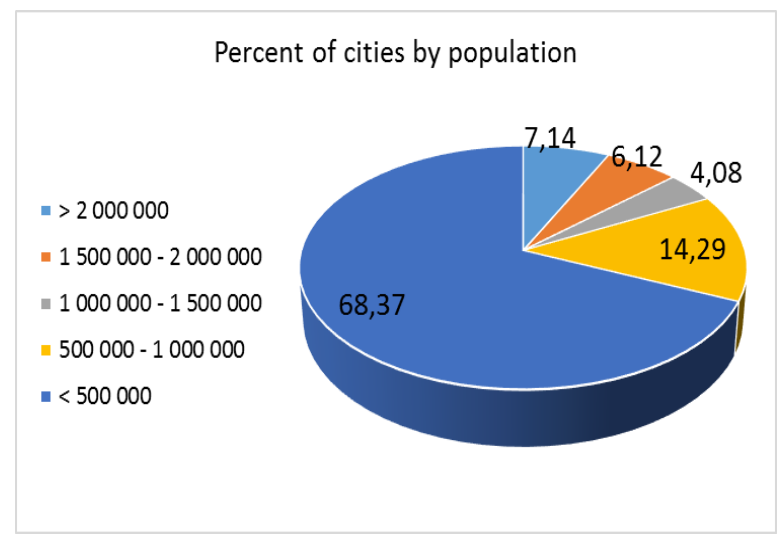

Fig. 1. Percent of cities by population. 


\section{METHODS}

Several methods can be used to understand population density in urban areas (Montgomery, 2008; Silva and Poelman, 2016). But in this study, we will see the population density of the chart patterns and density maps occurring in those cities (Kolejka et al., 2015). This research is done through several steps, namely:

(1) Collect data from 15 cities in Indonesia (CBS, 2016). The data are data on population, area, district data available in each city, distance from center to city to district center, district administrative boundary map, and other information to strengthen understanding of conditions in each city.

(2) Create a table of cities based on population, area and city density. City density is obtained from the division of population and area (ha).

(3) Creating tabulation of district data in each city, covering population, area, and distance of district center to city center. Then, analyzed to determine the population density. From this table, analysis of the correlation between the density of district residents with the distance of the district center to the city center. Analyze is done by using SPSS software version 16 to know the value of significance (Sig). If the Sig score is $<5 \%$, this means that there is a correlation between population density and district distance to the city center, and vice versa. This is done to determine the pattern of density and distance relationships for the Indonesian context.

(4) Population density data and district center distance to the city center are presented in the graph to see distribution trend. If the line graph pattern shows density in the city center is higher when compared with the density of the suburb, then this means the city has a compact city criteria.

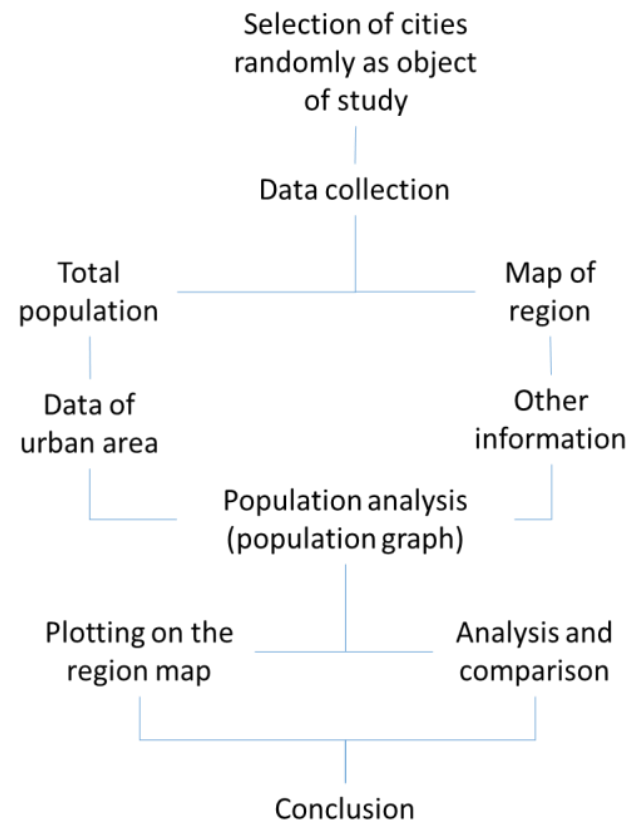

Fig. 2. The research flow in this study. 
(5) Create degradation map of population density. This map is compared with the density line graph and distance in each city. This is done to test the correctness of the line graph with the density phenomenon indicated by the map with color degradation showing the difference in density.

(6) Establish a population density group based on the distance from the city center. This is the basis for compiling the graph of population density line to see the graph form. If high density is in the city center and low on the edge of the city, then that means the population density is perfectly spread out, and this indicates that the city has a compact city criteria. The flow in this research can be seen in Fig. 2 .

\section{RESULTS AND DISCUSSION}

For the first step, we collect the data from 15 cities across in Indonesia. The data obtained from the Central Bureau of Statistics Indonesia. The cities are samples spread in some of the largest islands in Indonesia, namely the island of Java, Sumatra Island, Borneo Island, Island of Bali, and the island of Sulawesi. The city is randomly selected, but the population is in the range of 500,000 - 1,500,000 people. Furthermore, the cities were made graphs covering the city's charts based on population size, area (ha) and population density (see Fig. 3). From the available data, we can know that the highest population in Tangerang Selatan City is $1,593,812$ people and the city with the lowest population is Manado City which is 425,634 people. Based on the widest area, the largest city is Samarinda City which is 71,711 $\mathrm{Ha}$, and the narrowest city is Banjarmasin which is 9,846 Ha. Meanwhile, the most populous city is Tangerang Selatan, 108.28 people/ha and the city with the lowest density is Samarinda City which is 10.89 people/Ha. As a note, the density of urban dwellers district will be different (see Table 1 and Fig. 3).

Table 1. The cities base on amount of districts, density, distance and Sig. Value.

\begin{tabular}{|c|c|c|c|c|c|}
\hline \multirow[t]{2}{*}{ No } & \multirow[t]{2}{*}{ Cities } & \multirow{2}{*}{$\begin{array}{c}\mathrm{N} \\
\text { District }\end{array}$} & \multicolumn{2}{|c|}{ Density in district (people $\mathrm{ha}^{-1}$ ) } & \multirow{2}{*}{$\begin{array}{l}\text { Sig. Value (density \& } \\
\text { distance correlation) }\end{array}$} \\
\hline & & & High Density & Low Density & \\
\hline 1 & Samarinda & 10 & 56.75 & 2.36 & 0.080 \\
\hline 2 & Padang & 11 & 95.54 & 2.27 & 0.654 \\
\hline 3 & Batam & 12 & 82.49 & 0.48 & 0.003 \\
\hline 4 & Pekan Baru & 12 & 125.46 & 4.11 & 0 \\
\hline 5 & Serang & 6 & 80.01 & 9.51 & 0.024 \\
\hline 6 & Manado & 11 & 140.66 & 3.66 & 0.007 \\
\hline 7 & Tasikmalaya & 10 & 134.67 & 18.23 & 0.001 \\
\hline 8 & Palembang & 16 & 105.39 & 8.99 & 0.001 \\
\hline 9 & Bandar Lampung & 20 & 182.8 & 24.29 & 0.009 \\
\hline 10 & Pontianak & 6 & 101.09 & 32.57 & 0.826 \\
\hline 11 & Denpasar & 4 & 104.09 & 54.63 & 0.069 \\
\hline 12 & Banjarmasin & 5 & 142.27 & 41.20 & 0.215 \\
\hline 13 & Malang & 5 & 119.94 & 43.74 & 0.738 \\
\hline 14 & Bogor & 6 & 128.07 & 63.02 & 0.231 \\
\hline 15 & $\begin{array}{l}\text { Tangerang } \\
\text { Selatan }\end{array}$ & 7 & 133.98 & 56.61 & 0.696 \\
\hline
\end{tabular}


For the second step, each city has several districts with diverse population and area. We collect district data in each city. In total, the number of districts in 15 cities are 141 districts. The city with the most districts exist in the city of Bandar Lampung (20 districts), and the city with the least district is the city of Denpasar (4 districts). District data in each city are included in the data table of population and area per district in each city. District data in each city were analyzed for population density. The result is the identification of districts with the highest and lowest densities as seen in Table 1.

We also collected data about the distance from the district center to the city center. This data is obtained from BPS and reconfirmed using data from Google map using the straight line. And the results can be said to be the same between BPS and Google Map data. Then, each city, we analyzed the correlation or relationship between population density per district and district distance from city center using SPSS. The result is eight districts indicate there is a relationship between density and distance, and seven districts are showing no correlation between population density and distance. This correlation was obtained from the SPSS analysis which determined that; If the value of Sig $<5 \%$ then it indicates there is the correlation, and vice versa. In this study, all cities will be explored, both with $\mathrm{Sig}<5 \%$ and $\mathrm{Sig}>5 \%$.

The correlation test in Table 1 between density and distance is performed in each city to make the groupings of cities that have correlation and which have no correlation between density and distance. Because, we hypothesized that the further away from the city center, the density will decrease. Or vice versa, the farther away from the city center the density will increase. The correlation between the density and distance can be seen from the correlation test conducted. And as mentioned earlier that there are eight cities have correlations between density and distance, and there are seven cities that have no correlation between the density and distance from the city center. From this condition, we can say that amount of cities in Indonesia have correlation between density and distance from city center. This will be one of the topics of discussion.

(a). The cities by population.

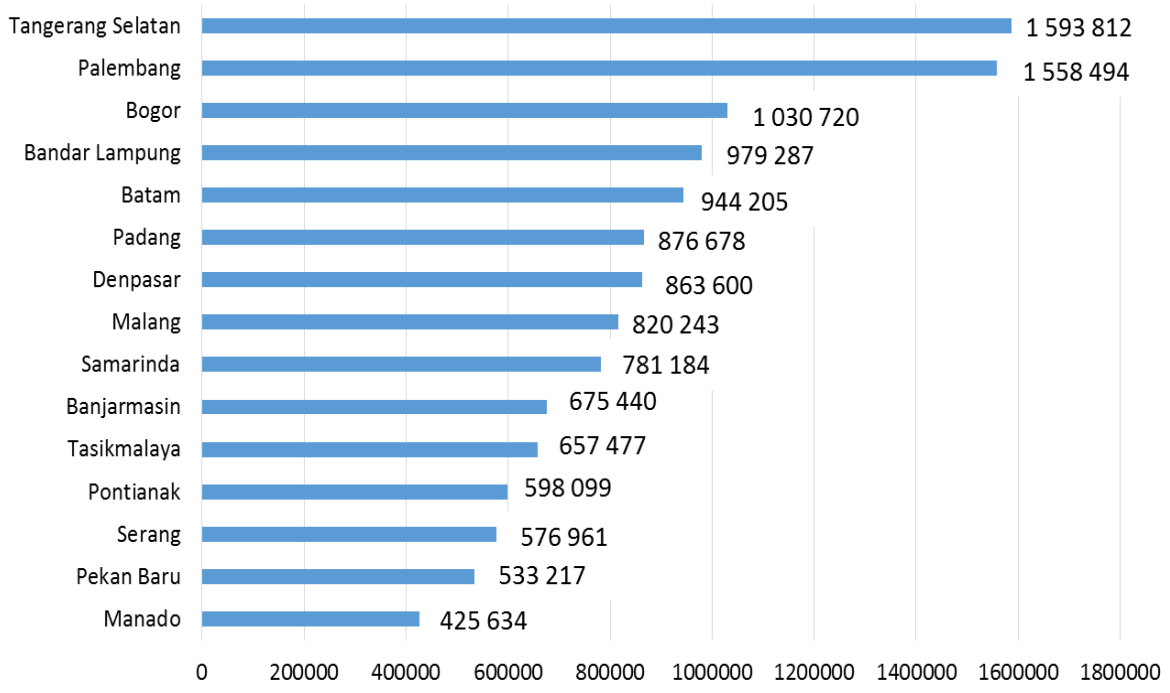


(b). The cities by area (ha).

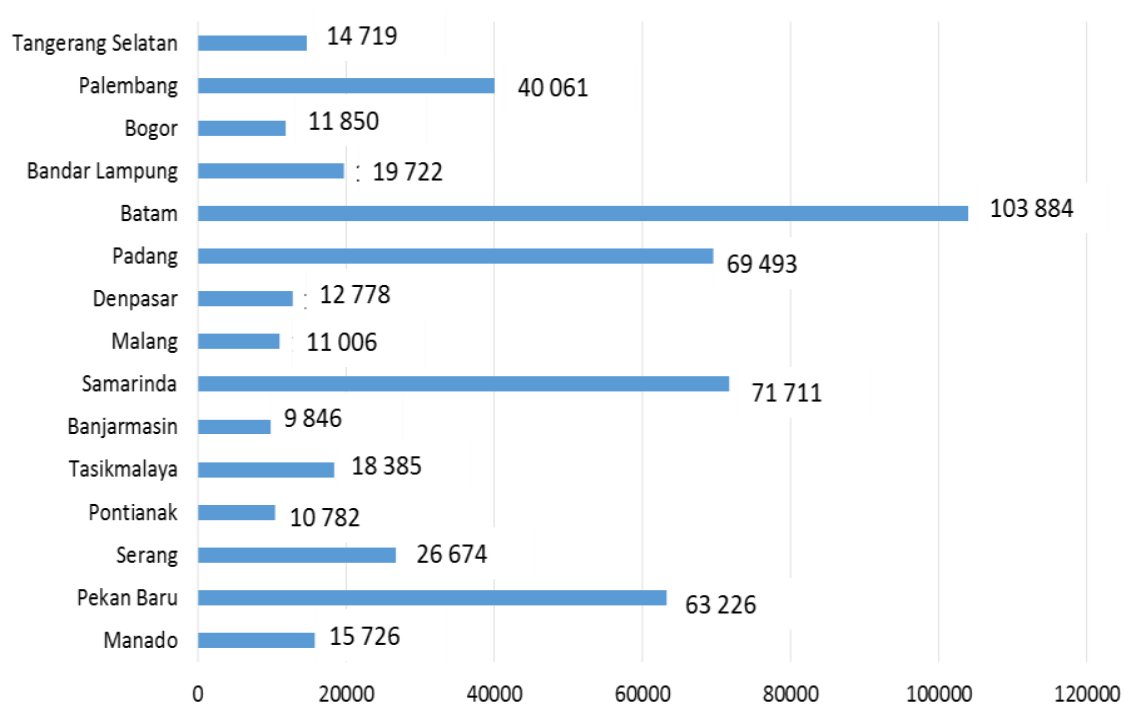

(c). The cities by density (pop/ha).

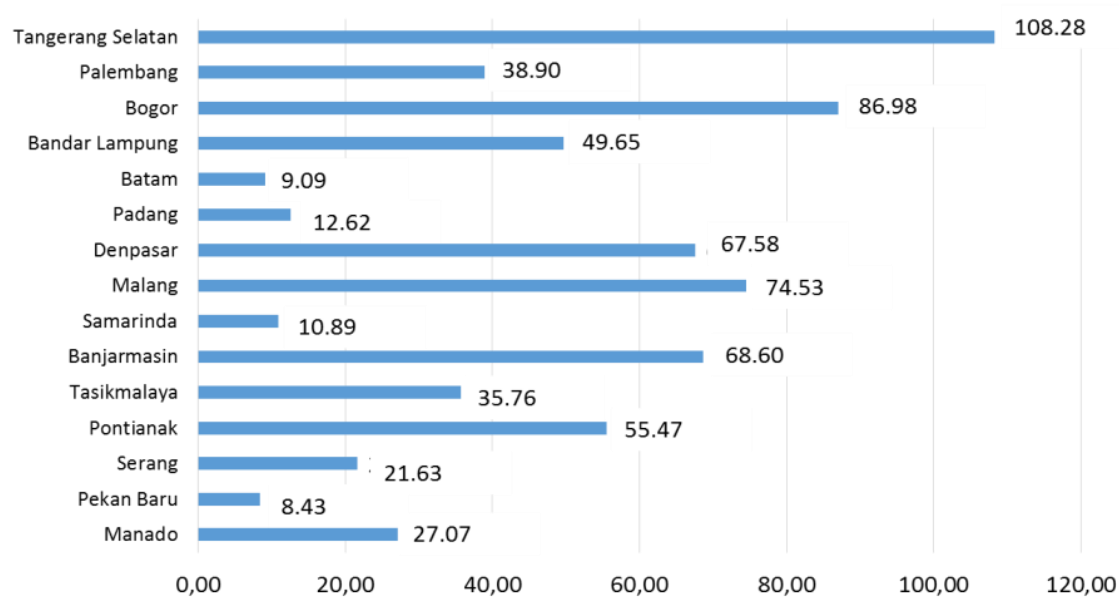

Fig. 3. The cities base on (a) population, (b) area and (c) density.

In the third step, we made a graph of the relationship between density and distance in each city per district. The graph is 15 lines and united in one figure with " $\mathrm{X}$ " as distance and "Y" as density. The results can be seen in Fig 4. We convey two cities which have districts in separate island. Both cities are Batam City and Manado City. Batam City has four districts located in separate islands, they are Belakang Padang, Nongsa, Galang, and Bulang districts.

Then, Manado City has one district which is located on the separate islands, it is Bunaken Kepulauan District. Since the islands are separate, so the core city has little influence on the development of the district. So we only use the district data in each city that is on the same island or the same land without being separated by the sea waters. 


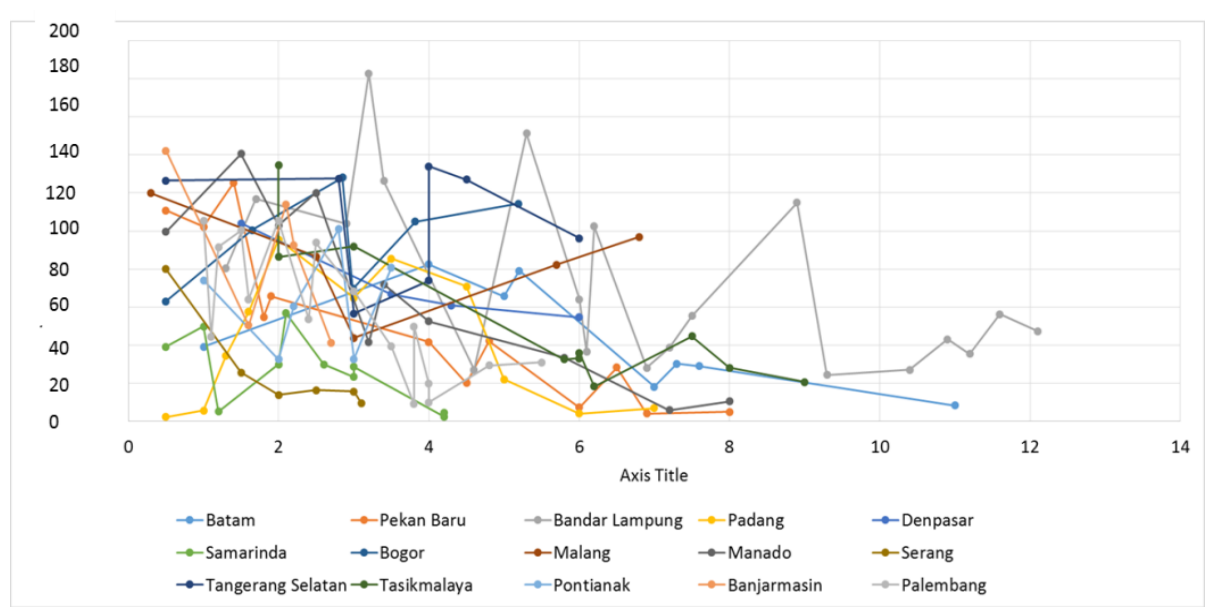

Fig. 4. Graphs of density and distance.

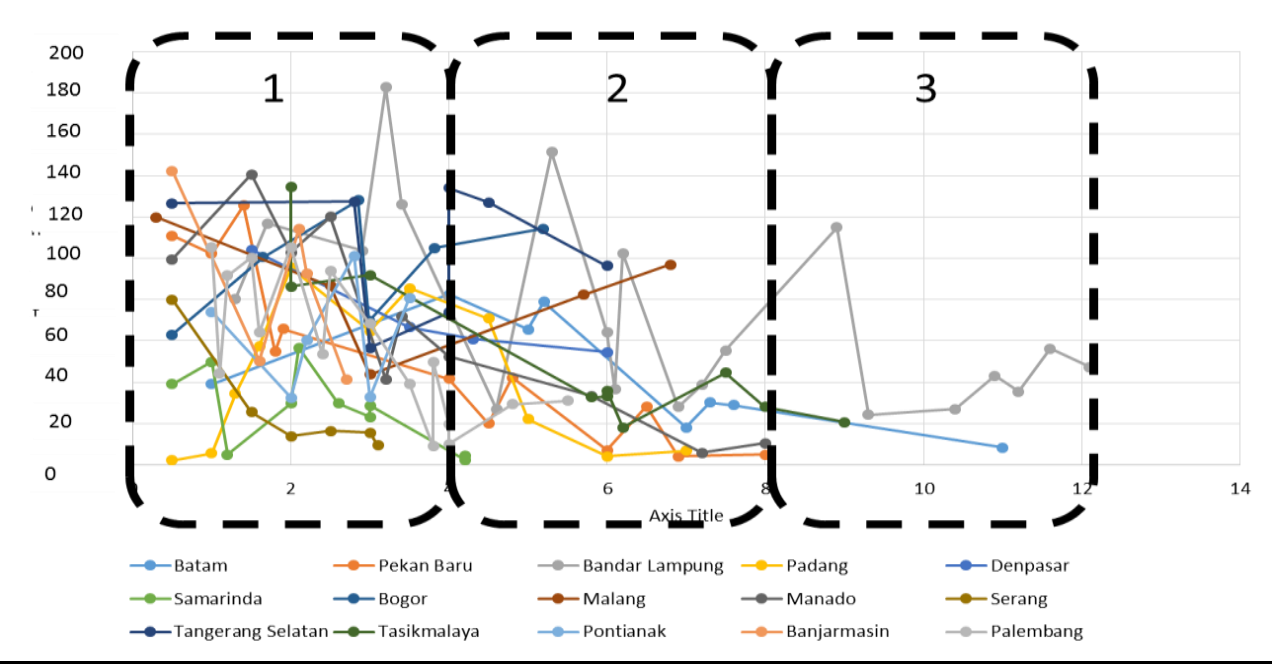

Fig. 5. The groups of density and distance in all cities (people ha ${ }^{-1}$ ).

As can be seen in Fig. 4, the graph illustrates the condition of the density graphic pattern that still incorporates the data of the districts residing on a separate island. While the figure shows a compilation of a line map that only covers district data in the same land. Fig 3 show an extensive collection of points in areas close to the center of the city, then gradually decreasing as they get further from the city center. We can say that there is a trend of high population density in areas close to the city center and decreases if further from city center. To check it, we will see using the city map by district through color degradation indicating density in each district.

In the fourth step, we made a map of the city based on the population in each district. Each color represents a certain density. Staining consists of 6 levels namely as seen in Table 2. The maps have colors degradation based on this population density compiled with a line chart per city based on the comparison of density and distance from downtown in 
each city. The line graph in Table $\mathbf{3}$ is the same as the line graph in Fig. 3, which is a collection $\mathrm{n}$ of all the density and distance line graphs in all districts in each city.

The combined table between the line graph and the population density map shows that there is indeed a trend that population density will be higher if near the center of the city. Although, these conditions do not occur in all cities. Discussions of these various density conditions need to be examined again in the future. Two cities have anomalous graphs when compared to other city charts. The two cities are Banjarmasin and Bogor. The density and distance charts in Banjarmasin City showed a decrease from the city center to the suburbs, but the Sig value $>5 \%$.

Table 2. Map of cities.

$\begin{array}{llcl}\text { No } & \text { Level } & \text { Degradation } & \text { Colour } \\ 1 & \text { Level 1 } & 0.00-35.00 & \\ 2 & \text { Level 2 } & 35.01-70.00 & \\ 3 & \text { Level 3 } & 70.01-105.00 & \\ 4 & \text { Level 4 } & 105.01-140.00 & \\ 5 & \text { Level 5 } & 140.01-175.00 \\ 6 & \text { Level 6 } & 175.01-210.00 & \end{array}$

The graph for the town of Bogor shows a high increase from the city center to the suburbs but the value of Sig 0.231 or close to $5 \%$, whereas it should have a higher value (> 0.231). But in this study, this anomaly will be ignored. The map in Table 3 does not have a scale because it is only to see the trend of changing population density from downtown to the suburbs. The previous step shows that the graphic pattern of the relationship between density and distance from the city center in 15 cities is indeed like that. With these considerations, this research continues to the next step.

Furthermore in the fifth step, based on the aggregate graph of the relationship between density and distance, we see that the chart can be made into three groups based on a range of fields:

1. Group $1=1 \mathrm{~km}$ to $4 \mathrm{~km}$

2. Group $2=4.01 \mathrm{~km}$ to $8 \mathrm{~km}$

3. Group $3=8.01 \mathrm{~km}$ to more

This grouping is based on the distance trends presented on the graph and sees the tendency of a collection of districts with an absolute density in the chart. From the graph, we can know that the district which is located farthest away from downtown is Panjang, located in Bandar Lampung, the distance reaches $12.1 \mathrm{~km}$.

This grouping results in the compilation of data as shown in Table 4, i.e., population data, population percentage and average density per distance group from city center. Table 3 shows that many residents are in group $1(0 \mathrm{~km}$ to $4 \mathrm{~km})$ which means the closest zone to the city center. The population is 8150979 or $62.06 \%$ of the total population in all cities. And the number of people living in zones in groups 2 and 3 was $34.14 \%$ and $3.81 \%$. We can say: the population is declining further from the city center. The graph can be seen in Figs. 4 and 5.

Meanwhile, the mean density for each particular distance group can be seen in Table 3. Fig. 6 shows that the highest average population density is in areas close to the city center and will decrease if it is further away from the city center. Population density in zones near the city center averaged 73, zone 2 averaging 42 and zone 3 averaging 41 . If we look at the graph of population density and the distances in Figs. 6a and $6 \mathbf{b}$, we can say that the graph is perfect and in line with the hypothesis that; The population density will decrease if it is away from the city center. 
Table 3. The cities base on line graph and density map.

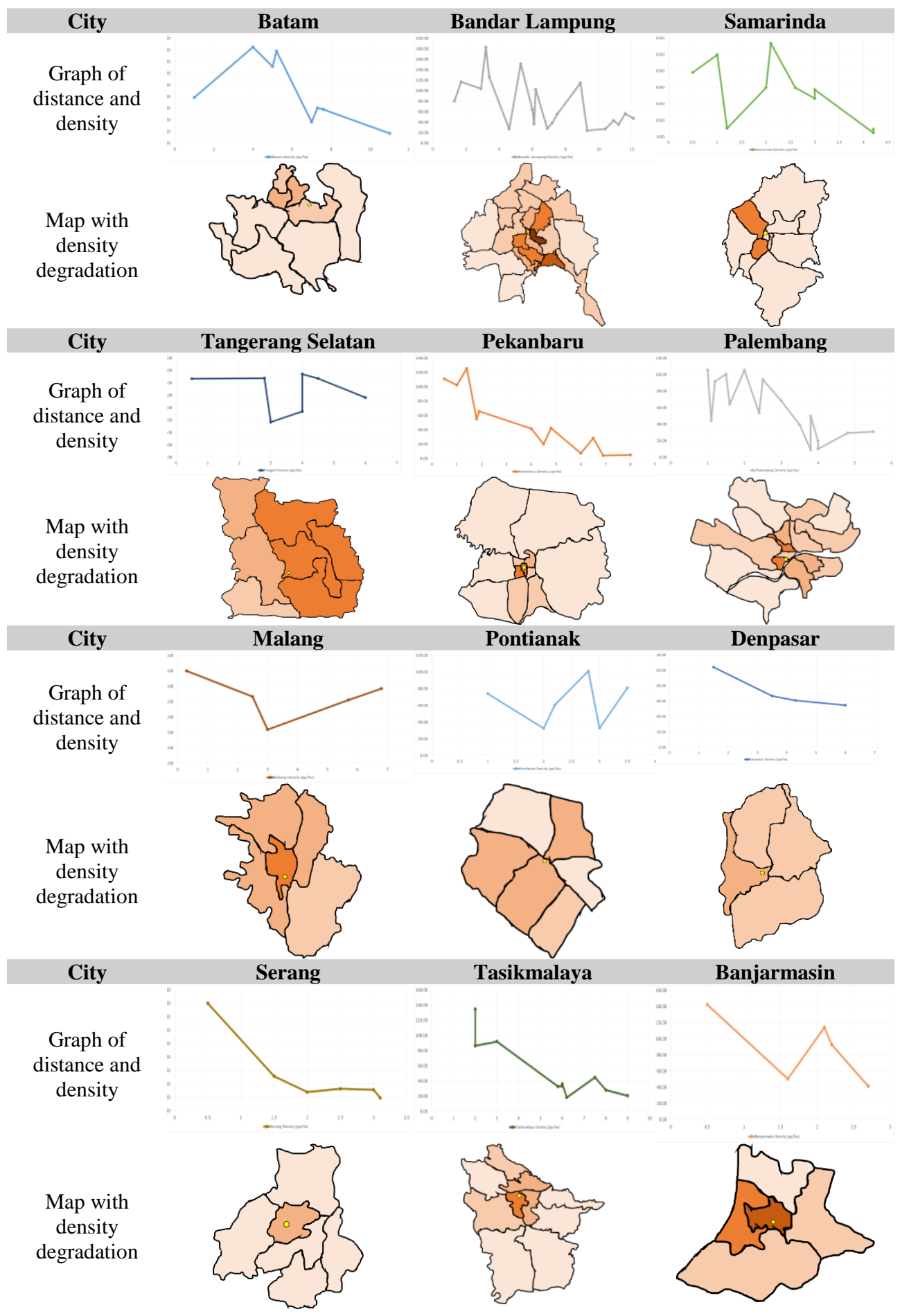




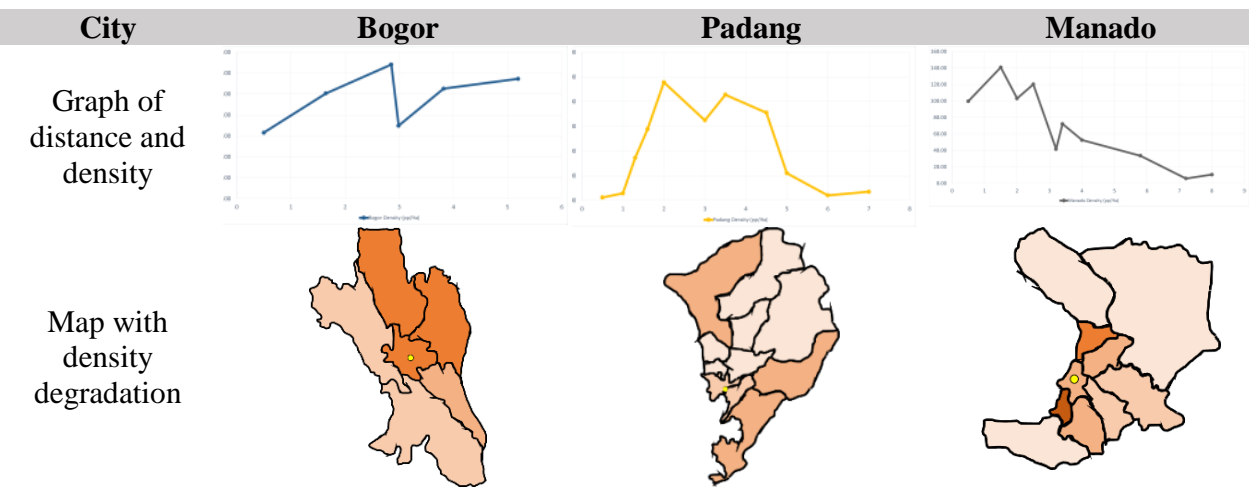

Table 4. The groups base on population, percent of population and density average.

\begin{tabular}{llll}
\hline \multicolumn{1}{c}{ GROUP } & POPULATION & $\begin{array}{c}\text { PERCENT from } \\
\text { total population }\end{array}$ & $\begin{array}{c}\text { Average of Density } \\
\left(\mathbf{p} / \mathbf{k m}^{\mathbf{2}}\right)\end{array}$ \\
\hline $1(0-4 \mathrm{Km})$ & $8,150,979$ & $62.06 \%$ & 72.527 \\
\hline $2(4.01-8 \mathrm{Km})$ & $4,483,575$ & $34.14 \%$ & 42.168 \\
\hline $3(8.01-12 \mathrm{Km})$ & 499,940 & $3.81 \%$ & 41.256 \\
\hline & $13,209,000$ & $100 \%$ & \\
\hline
\end{tabular}
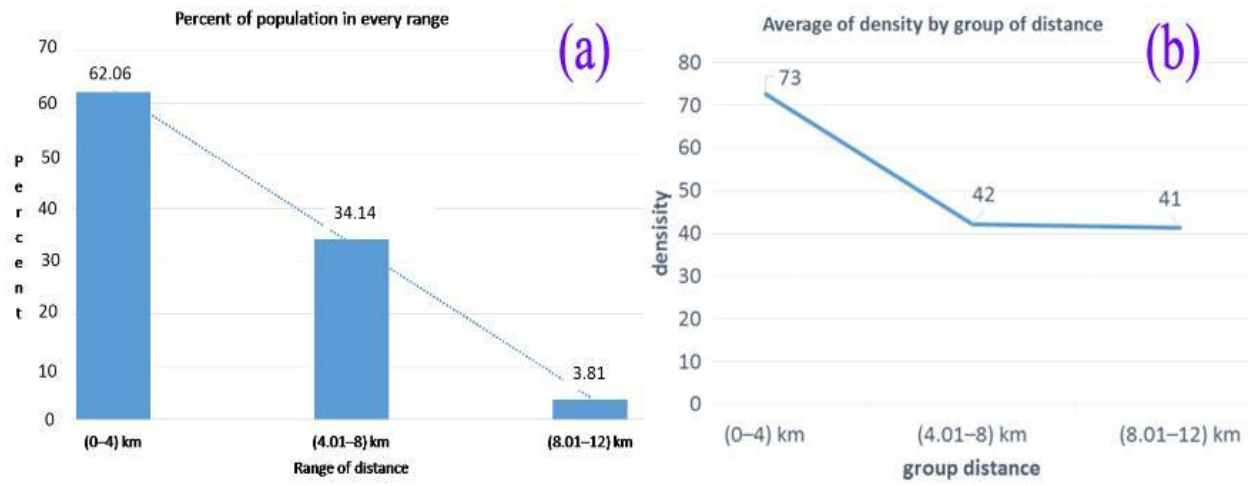

Fig. 6. Percent of population (a) and average of density in each range distance (b).

\section{CONCLUSION}

The results of the analysis show us that the pattern of population density charts from downtown to the suburbs is perfectly shaped. The city center has a high population density because the area has economic activity and usually has the completeness of public facilities, so the community will try to live near the city center. Although, they must stay on the land of others (riding) or in the forbidden area (rivers or railroads). And this means that the towns in Indonesia as the country with the economic level number 16 in the world has a city that has been included in the category of the compact city when viewed from the characteristic of population density. And this is good news for the city government in Indonesia because the government just to improve the quality of community settlements. 
Meanwhile, related to the number and density of the population, the government is required to control the number, and population density from downtown to the suburbs can be maintained. Indonesia is also fortunate that its population pattern of urban land use is well established. As we know, city governments in the world are experiencing the challenges of urban development in the field of population. Local authorities are aware that they need to set up residential locations for more people living near the city center. Because there are many advantages to being gained if more people live near the city center.

If many people live in the area near the city center, then the government can save money because the government does not need to build transportation infrastructure, clean water, sewage, garbage, energy, and telecommunications, to all areas of the city. Therefore, the construction of various infrastructures is expensive. Areas far from downtown can be maximized to green open spaces, rainwater catchments, natural attractions as well as agricultural areas to sustain the needs of the townspeople. Understanding of population density from downtown to the suburbs can assist the government in developing infrastructure development plans and controlling urban land use.

Cities in developing countries, such as Indonesia, often ignore population density based on distance from downtown. In fact, it is not only ignored but not a consideration in the preparation of urban spatial plans. As a result, the arranged layout creates problems in the future. Because, settlements and economic centers appear in many places randomly, bringing environmental and other issues such as the provision of transport infrastructure, electricity, gas, clean water, and waste control. The population density element does look simple for urban planning, but in fact, the population and location of the residence will have a profound effect on the city's future. The more serious consequence is that city planning that ignores population will bring a sprawl city form for itself. In fact, urban space control aims to direct the physical form of a compact city.

But Indonesia is fortunate, from the 15 cities we investigated, the population density in the city center, on average higher than in the suburbs. It indicates that the pattern of urban population has shown compact city criteria. But such a population condition would be an urban problem if not the primary consideration in urban planning. The object of our study indicates that this pattern of population density is naturally formed. That is residents, attempt to live close to the center of the city as an economic center with a reason to facilitate all activities and fulfillment of life needs. However, this happens not through design by the government. Therefore, the population factor is not a consideration in urban space utilization arrangements. However, knowing how much population density we do in this study can be a way for governments to understand patterns of population density in every other city. It is hoped that through this method, both private and government planners can develop a population density control plan in each city, tailored to the vision of each city. This method is very useful in urban spatial planning based on population density in each district and its distance from the city center.

\section{ACKNOWLEDGEENTS}

The researcher would like to thank the Japanese government for funding education and research. Finally, I also thank all members of Bart Lab who have given criticism and suggestions in every internal discussion, either directly or indirectly. Every deficiency in this research is the responsibility of the author. 


\section{REFERENCES}

CBS (2016) City in Figures in 2010, 2011, 2012, 2013, 2014, 2015. Central Bureau of Statistics of Indonesia, Jakarta.

Creutzig, F., Baiocchi, G., Bierkandt, R., Pichler, P. P. \& Seto, K. C. (2015) Global typology of urban energy use and potentials for an urbanization mitigation wedge. PNAS, 112 (20), 62836288.

Guneralp, B., Zhou, Y., Urge-Vorsatz, D., Gupta, M., Yu, S., Patel, P. L., Fragkias, M., Li, X., Seto, K. C. Global scenatios of urban density and its impacts on building energy use through 2050. PNAS, 114 (34), 8945-8950.

Jones, B. \& O'Neill, B C. (2016) Spatially explicit global population scenarious consistent with the shared socioeconomics pathways. Environmental Research Letters, 11 (8), https://doi.org/10.1088/1748-9326/11/8/084003.

Kolejka, J., Źyszkowska, W., Batelková, K., Ciok, S., Dołzbłasz, S., Kirchner, K., Krejčí, T., Raczyk, A., Spallek, W. \& Zapletalová, J. (2015). ppermeability of czech-polish border using by selected criteria. Geographia Technica, 10 (1), 51-65.

Moos, M. (2015) From gentrification to youthification? The increasing importance of young age in delineating high-density living. Urban studies, 53 (14), 2903-2920. https://doi.org/10.1177/0042098015603292.

Montgomery, M. R. (2008) The urban transformation of the developing world. Science, 319 (5864), 761-764. https://doi.org/10.1126/science.1153012.

Oueslati, W., Alvanides, S. \& Garrod, G. (2015) Determinants of urban sprawl in European cities. Urban studeis, 52, (9), 1594-1614. https://doi.org/10.1177/0042098015577773.

Papageorgiou, Y. Y. (2014) Population density in a central-place system. Journal of Regional Science, 54 (3), 450-461.

Silva, F. B. \& Poelman, H. (2016) Mapping population density in functional urban areas, JRC Technical Reports, European Commission. DOI:10.2791/06831.

Su, H, Wei, H. \& Zhao, J. (2016) Density effect and optimum density of the urban population in China. Urban Studies 54 (7), DOI: https://doi.org/10.1177/0042098015624839.

Yin, N. S., Siong, H. C. (2010) The relationship between urban population density and transportation fuel consumption in Malaysian Cities. Planning Malaysia Journal, 8, http://dx.doi.org/10.21837/pmjournal.v8.i1.79. 